\title{
COMPARATIVE ANALYSIS OF THE POLARIZATION AND MORPHOLOGICAL CHARACTERISTICS OF ELECTROCHEMICALLY PRODUCED POWDER FORMS OF THE INTERMEDIATE METALS
}

\author{
Nebojša D. Nikolić ${ }^{1 *}$, Predrag M. Živković ${ }^{2}$ Bojan Jokić ${ }^{2}$ \\ Miomir G. Pavlović ${ }^{1}$, Jasmina S. Stevanović ${ }^{1}$ \\ ${ }^{1}$ ICTM - Institute of Electrochemistry, University of Belgrade, Njegoševa 12, 11000 Belgrade, Serbia \\ ${ }^{2}$ Faculty of Technology and Metallurgy, University of Belgrade, Karnegijeva 4, Belgrade, Serbia \\ nnikolic@tmf.bg.ac.rs
}

The polarization and morphological characteristics of powder forms of the group of the intermediate metals were examined by the analysis of silver and copper electrodeposition processes at high overpotentials. The pine-like dendrites constructed from the corncob-like forms, which are very similar to each other, were obtained by electrodeposition of these metals at the overpotential belonging to the plateaus of the limiting diffusion current density. A completely different situation was observed by the electrodeposition of silver and copper at the overpotential outside the plateaus of the limiting diffusion current density in the zone with the fast increase in current density with the overpotential. Silver dendrites, which were very similar to silver and copper dendrites obtained inside the plateaus of the limiting diffusion current density, were obtained at the overpotential outside the plateau. Due to the lower overpotential for hydrogen evolution for copper, hydrogen produced during the copper electrodeposition process strongly affected the surface morphology of copper. The same shape polarization curves with completely different surface morphologies of $\mathrm{Cu}$ and $\mathrm{Ag}$ electrodeposited at overpotentials after the inflection point clearly indicate the importance of morphological analysis in the investigation of polarization characteristics of the electrodeposition systems. The role of hydrogen as a crucial parameter in the continuous change of copper surface morphology from dendrites to honeycomb-like structures was investigated in detail. On the basis of this analysis, the transitional character of the intermediate metals between the normal and inert metals was considered. The typical powder forms characterising electrodeposition of the intermediate metals were also defined and systematized.

Keywords: electrodeposition; copper; silver; dendrite; hydrogen; pores; cauliflower-like forms

\section{СПОРЕДБА НА ПОЛАРИЗАЦИОНИТЕ И МОРФОЛОШКИТЕ КАРАКТЕРИСТИКИ НА ЕЛЕКТРОХЕМИСКИ СОЗДАДЕНИ ПРАШКОВИДНИ ОБЛИЦИ НА ИНТЕРМЕДИЈАРНИ МЕТАЛИ}

\footnotetext{
Преку анализа на процесите на електродепозиција на сребро и бакар при високи пренапони беа испитувани и споредувани поларизационите и морфолошките карактеристики на прашоци од интермедијарни метали. При електродепозиција на овие метали со пренапони што припаѓаат на платото на гранична дифузиона густина на струјата, беа добиени дендрити во вид на бор изградени од елементи слични на кочан од пченка, кои се многу слични еден на друг. Наполно поинаква состојба беше утврдена при електродепозиција на овие метали со пренапони надвор од платото на гранична дифузиона густина на струја во делот на брз пораст на густината на струјата. Дендрити на среброто, многу слични на оние на дендритите на сребро и бакар добиени при пренапони што припаѓаат на платото на гранична дифузиона густина на струјата, беа добиени при пренапони надвор од оние на платото. Поради помалиот пренапон за издвојување на водород врз бакар, водородот создаден врз овој метал нагласено ја менуваше морфологијата на површината на бакарот. Истиот облик на поларизационите криви при целосно различни морфологии на
} 
површината на $\mathrm{Cu}$ и $\mathrm{Ag}$ создадени при електродепозиција со пренапони повисоки од оние што одговараат на точката на инфлексија, сосем јасно ја нагласуваат важноста на анализата на морфолошките облици при испитување на поларизационите карактеристики на даден систем на електродепозиција. Улогата на водородот како параметар со круцијална важност за континуираното менување на морфологијата на површината на бакарот од дендритна до структура слична на саќе со мед, беше испитувана во детали. Врз основа на ваквата анализа беше утврдено дека карактерот на интермедијарните метали се менува од оној сличен на нормалните во оној на инертните метали. Исто така беа дефинирани и систематизирани типичните облици на прашоците што ја карактеризираат електродепозицијата на интермедијарните метали.

Клучни зборови: електродепозиција; бакар; сребро; водород; пори; депозити со облик сличен на карфиол

\section{INTRODUCTION}

The surface morphology, as the most important characteristic of electrodeposited metal, mainly depends on the kinetic parameters during the electrodeposition process and on the overpotential or current density applied [1]. Also, compositions of electroplating solutions, temperature, time of electrolysis and the type of working electrode strongly affect the final morphology of electrodeposited metal.

According to their general kinetic behaviour in aqueous solution, metals can be classified into three classes [2,3]. These classes are:

(a) Class I, so-called normal metals: $\mathrm{Pb}, \mathrm{Sn}$, $\mathrm{Tl}, \mathrm{Cd}, \mathrm{Hg}, \mathrm{Ag}$ (simple electrolytes), Zn. These metals have characteristic low melting points and high exchange current densities $\left(j_{0}>1 \mathrm{~A} \mathrm{dm}^{-2} ; j_{0}\right.$ is the exchange current density). Also, they show high overpotentials for hydrogen discharge.

(b) Class II, intermediate metals: $\mathrm{Cu}, \mathrm{Au}, \mathrm{Ag}$ (complex electrolytes). These metals are characterized by moderate melting points, medium exchange current densities $\left(j_{0}\right.$ in the interval from $10^{-2}$ to $1 \mathrm{~A} \mathrm{dm}^{-2}$ ) and lower hydrogen overpotentials.

(c) Class III, inert metals: $\mathrm{Fe}, \mathrm{Co}, \mathrm{Ni}, \mathrm{Mn}$, $\mathrm{Cr}, \mathrm{Pt}$. These metals have high melting points, low exchange current densities and very low hydrogen overpotentials. For this class of metals, $j_{0}$ is between $10^{-2}$ and $10^{-12} \mathrm{~A} \mathrm{dm}^{-2}$.

The most often irregular (or powder) morphological forms obtained by the electrodeposition processes are: dendrites, flakes, fibrous, spongy, nanowires, the honeycomb-like structures and cauliflower-like particles [4-26]. These forms may be either useful (the production of powders $[4-6,15$, $16]$ and the creation of open porous structures that are suitable for electrodes in electrochemical devices and in catalysis [17-25]) or undesirable (in electrowining and electrorefining processes, in batteries [27]).
From a technological point of view, the electrodeposition technique has been shown to be a valuable method for synthesis of the above-mentioned useful morphological forms. The main advantages of the formation of powders by electrolysis in relation to other methods of powder production (mechanical commuting, chemical reaction and liquid metal atomization) are the high purity of the produced powder, which can be easily pressed and sintered, and the low oxygen content [4]. The honeycomb-like or 3D (three-dimensional) foam electrodes are formed by the one-step electrodeposition process, where hydrogen bubbles function as a dynamic template for metal deposition, resulting in the creation of an open porous structure with an extremely large surface area [17]. Compared with hard templates, such as porous polycarbonate membranes, anodic alumina membranes, colloidal crystals and echinoid skeletal structures, the hydrogen bubble dynamic template method possesses several advantages: low cost, ease of preparation, facile control of structure, and facile one-step synthesis process, including preparation of the template, metal deposition, and elimination of the template [18].

As already mentioned, the group of intermediate metals is situated between the normal and inert metals, and it is logical to suppose that they possess some characteristics of both groups of metals. In spite of numerous investigations of the formation of powder forms of the intermediate metals via electrolysis, these investigations have been quite chaotic and unsystematic. Considering the various applications of these metals, the need for a systematization of their morphological characteristics is necessary.

In this review, the process used for the electrodeposition of copper and silver (the ammonium electrolyte) at high overpotentials will be analyzed and the obtained surface morphologies will be correlated with the corresponding polarization characteristics. In this way, powder morphological forms will be defined which characterise the in- 
termediate metals. Also, the mechanism for their formation and the transitional character between normal and inert metals will be considered.

\section{EXPERIMENTAL}

Silver electrodeposition. - Silver was electrodeposited from $0.1 \mathrm{M} \mathrm{AgNO}_{3}$ in $0.5 \mathrm{M}$ $\left(\mathrm{NH}_{4}\right)_{2} \mathrm{SO}_{4}$ solution to which ammonium hydroxide was added to dissolve the silver sulphate precipitate. Electrodeposition was performed at overpotentials of 650 and $1000 \mathrm{mV}$ on vertical cylindrical graphite electrodes. The polarization curve for silver electrodeposition was recorded using a platinum cylindrical electrode covered with thin silver film. This thin silver film was electrodeposited from the same solution at the overpotential of $150 \mathrm{mV}$ for $5 \mathrm{~min}$. The counter and reference electrodes were pure silver.

Copper electrodeposition. - Copper was electrodeposited from $0.1 \mathrm{M} \mathrm{CuSO}_{4}$ in $0.5 \mathrm{M}$ $\mathrm{H}_{2} \mathrm{SO}_{4}$ solution at overpotentials of $650,750,850$ and $1000 \mathrm{mV}$ on vertical cylindrical copper electrodes. The counter and reference electrodes were pure copper.

Double-distilled water and analytical grade chemicals were used for the preparation of solutions used for the electrodeposition of all metals. All experiments were performed in an open cell at room temperature. The counter-electrodes were corresponding metallic foils with $0.80 \mathrm{dm}^{2}$ surface area and were placed close to the cell walls. The reference electrodes were wires of the corresponding metals whose tips were positioned at a distance of about $0.2 \mathrm{~cm}$ from the surface of the working electrodes. The working electrodes were placed in the centre of a cell, in the same location for each experiment. The quantity of electricity was $10 \mathrm{~mA} \mathrm{~h} \mathrm{~cm}^{-2}$.

Morphologies of the copper and silver deposits were examined using a scanning electron microscope - TESCAN Digital Microscopy.

For determination of the average current efficiency of hydrogen evolution, an electrochemical cell with the same arrangement of copper electrodes as that used for the preparation of copper deposits for SEM analysis was employed. The electrodes were situated under a burette with the surface facing upwards so that the total amount of hydrogen evolved during the electrodeposition processes went into the burette. During the electrodeposition process, the volume of evolved hydrogen $V\left(\mathrm{H}_{2}\right)$ and the current of electrodeposition $I$ after a time $t$ were recorded. Then, after graphical integration $I-t$, the current efficiency for hydrogen evolution $\eta_{\mathrm{I}}\left(\mathrm{H}_{2}\right)$ in a time $t$ was determined according to Eq. (1):

$$
\eta_{\mathrm{I}}\left(\mathrm{H}_{2}\right)=\frac{V\left(\mathrm{H}_{2}\right)}{\mu\left(\mathrm{H}_{2}\right) \int_{0}^{t} I \mathrm{~d} t}
$$

where:

$$
\mu\left(\mathrm{H}_{2}\right)=\frac{V}{n F}=\frac{23900 \mathrm{~cm}^{3}}{2 \times 26.8 \mathrm{Ah}}=446 \frac{\mathrm{cm}^{3}}{\mathrm{Ah}}
$$

and $n F$ is the number of Faradays per mole of consumed ions and $V$ is the molar volume of a gas at a temperature of $18.0{ }^{\circ} \mathrm{C}$ (i.e. $23900 \mathrm{~cm}^{3}$ ). The average current efficiency of hydrogen evolution, $\eta_{\mathrm{I}, \mathrm{av}}\left(\mathrm{H}_{2}\right)$ is determined after graphical integration $\eta_{\mathrm{I}}\left(\mathrm{H}_{2}\right)-t$ as:

$$
\eta_{\mathrm{I}, \mathrm{av}}\left(\mathrm{H}_{2}\right)=(1 / t) \int_{0}^{t} \eta_{\mathrm{I}}\left(\mathrm{H}_{2}\right) \mathrm{d} t .
$$

The specification of the experimental procedure for the determination of the average current efficiency of hydrogen evolution is given by Nikolić et al. [19].

\section{RESULTS AND DISCUSSION}

\subsection{Polarization characteristics of the intermediate metals}

The polarization curves for the electrodeposition of copper and silver as the typical representatives of the group of intermediate metals are shown in Figure 1.

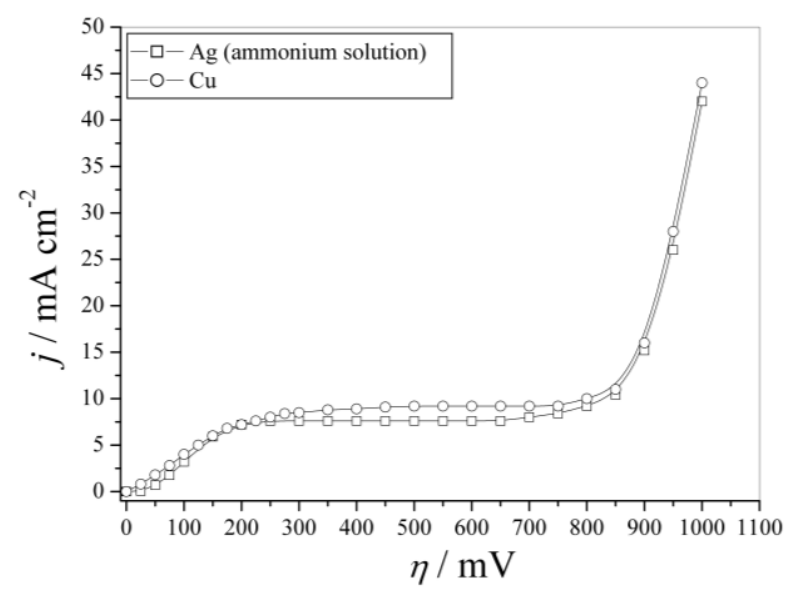

Fig. 1. The polarization curves for copper and silver electrodeposition 
The exchange current densities of $0.11 \mathrm{~mA}$ $\mathrm{cm}^{-2}$ for $\mathrm{Cu}$ [1] and $0.25 \mathrm{~mA} \mathrm{~cm}$ for $\mathrm{Ag}$ [28] clearly confirm the affiliation of these electrochemical systems to the group of metals characterized by the medium exchange current densities. At first sight, the polarization curves were very similar to each other, with well-defined plateaus of the limiting diffusion current density. The plateaus of the limiting diffusion current density were from 300 to $750 \mathrm{mV}$ for $\mathrm{Cu}$ and from 250 to $700 \mathrm{mV}$ for Ag. The end of the plateaus was determined by a sharp increase in the current density with a further increase in the overpotential.

\subsection{Morphologies of irregular forms of the inter- mediate metals obtained by electrodepositions at high overpotentials}

Figure 2 shows silver (Fig. 2, a and b) and copper (Fig. 2, c and d) deposits obtained at an overpotential of $650 \mathrm{mV}$, which belongs to the plateaus of the limiting diffusion current density. The very branchy 3D (three-dimensional) dendrites, which were very similar to each other, were the dominant morphological forms obtained by the electrodeposition of these metals. The shape of dendrites was pine-like (Fig. 2, a and c) with corncob-like forms as their basic element (Fig. 2, b and d). Aside from very branchy dendrites, small cauliflower-like forms were also obtained by electrodeposition at this overpotential. In the case of $\mathrm{Cu}$, the presence of individual holes formed from detached hydrogen bubbles (part in circles in Fig. 2 c) was also noticed. A completely different situation was observed during the electrodeposition of $\mathrm{Ag}$ and $\mathrm{Cu}$ at an overpotential of $1000 \mathrm{mV}$ (the parts of the polarization curves characterized by the fast increase in current density with increasing overpotential).

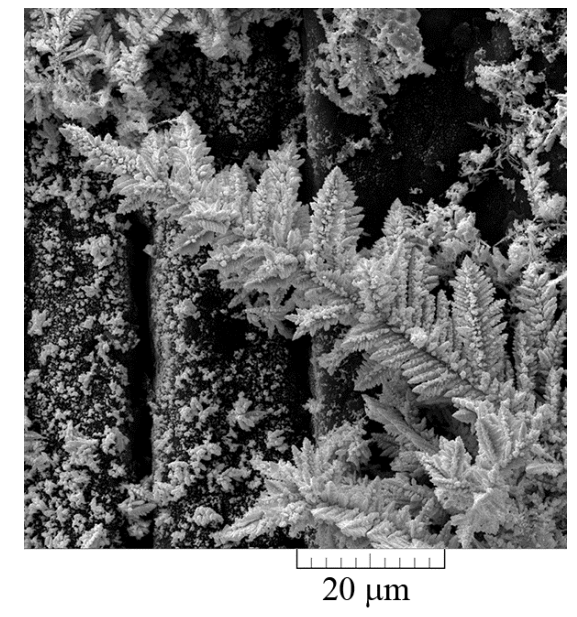

a)

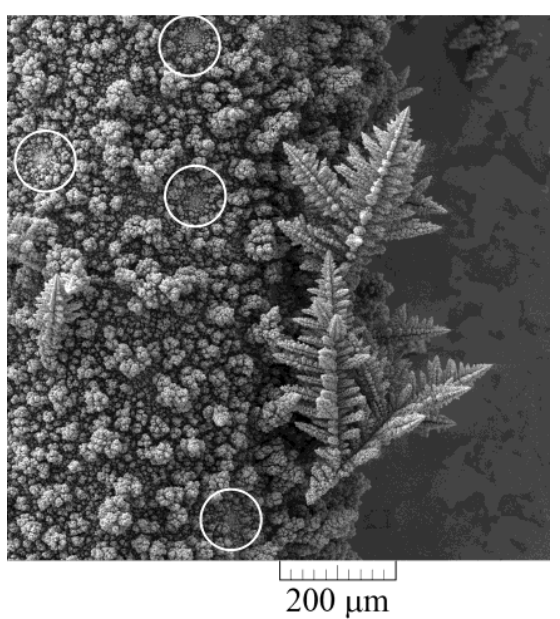

c)

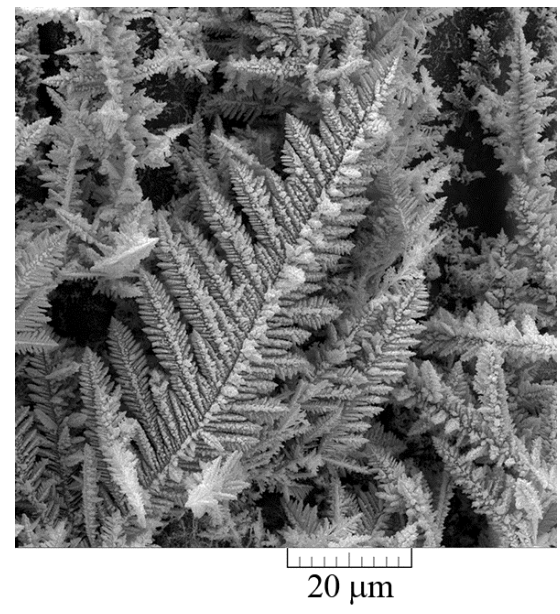

b)

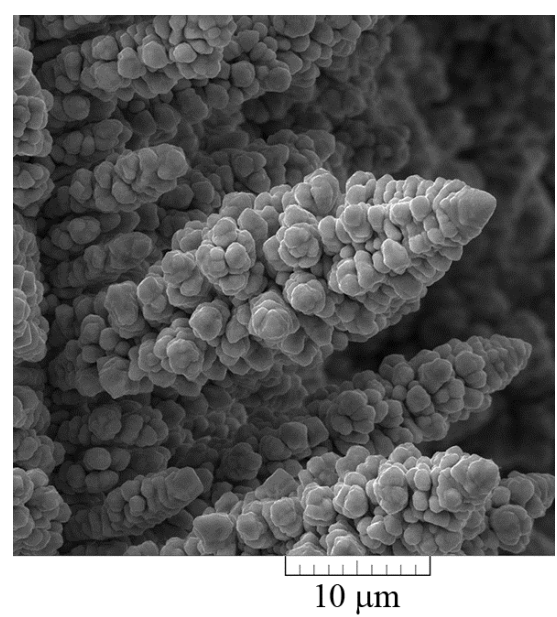

d)

Fig. 2. Morphologies of: a) and b) silver, and c) and d) copper deposits obtained by electrodeposition at an overpotential of $650 \mathrm{mV}$ 
The very branchy pine-like dendrites of $\mathrm{Ag}$, which were very similar to those electrodeposited at $650 \mathrm{mV}$, were obtained by electrodeposition at 1000 $\mathrm{mV}$ (Fig. 3, a and b). On the other hand, holes formed of detached hydrogen bubbles surrounded by the cauliflower-like agglomerates of $\mathrm{Cu}$ grains were formed by copper electrodeposition (Fig. 3, c and d). This type of structure represents the typical honeycomb-like structure and vigorous hydrogen evolution is responsible for its formation. The appearance of individual holes (Fig. 2 c) and formation of the honeycomb-like structure (Fig. $3 \mathrm{c}$ ) clearly confirms the fact that hydrogen evolution reaction on copper electrode is somewhat faster than on silver electrode [29]. In the case of $\mathrm{Ag}$, there is no hydrogen evolution even at an overpotential of $1000 \mathrm{mV}$ vs. Ag reference electrode.

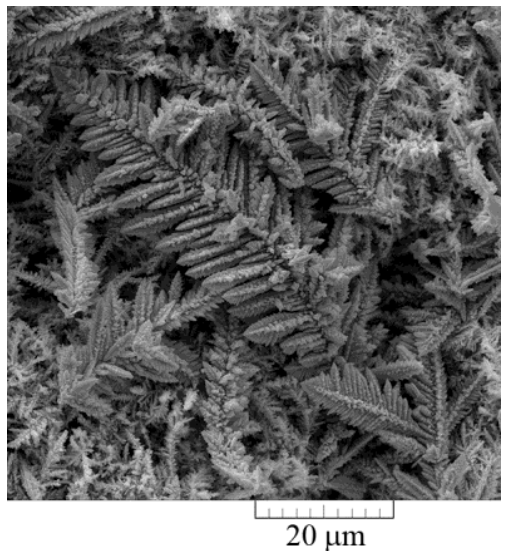

a)

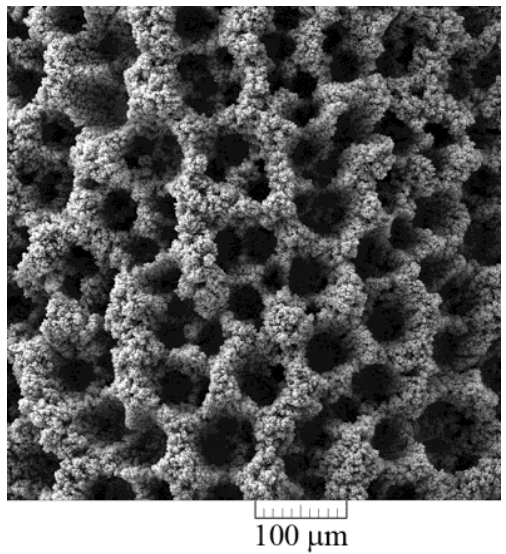

c)

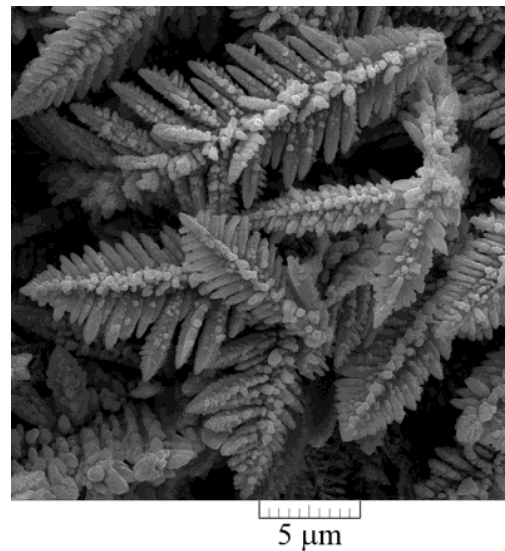

b)

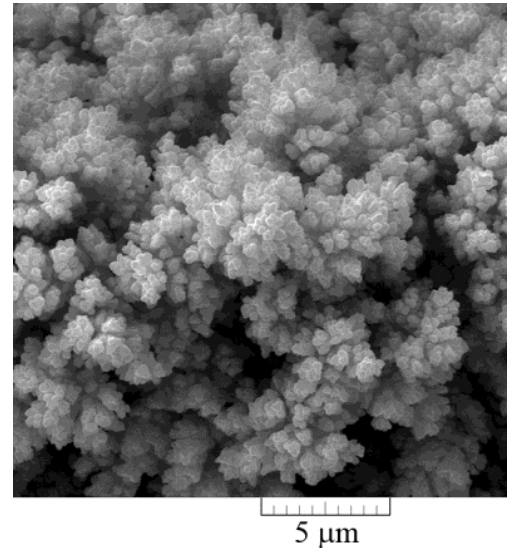

d)

Fig. 3. Morphologies of: a) and b) silver, and c) and d) copper deposits obtained by electrodeposition at an overpotential of $1000 \mathrm{mV}$

\subsection{Characteristics of dendritic growth of the intermediate metals}

The pine-like dendrites of $\mathrm{Cu}$ and $\mathrm{Ag}$ (Figs. 2,3 , a and b) are of high structural symmetry, consisting of a long trunk or stem with corncob-like forms oriented in all directions. It is interesting to note that the corncob-like forms were mutually parallel and oriented at an approximate angle of about $60^{\circ}$ in relation to the stalk or trunk, indicating the existence of the growth of silver and copper crystals in a preferential direction. The corncob-like copper and silver forms were constructed from small agglomerates of metal grains indicating the similarity between copper and silver dendrites, not only on the macro-level but to also on the micro-level. The treatment of copper dendrites using ultrasound [30] showed that the corncob-like forms represent the basic element of which these dendrites were constructed. In accordance with Wranglen's definition of a dendrite [31], it is clear that the corncob-like forms represent the primary branches of a dendrite.

From the electrochemical point of view, a dendrite is defined as an electrode surface protru- 
sion that grows under activation control, while electrodeposition to the macroelectrode is predominantly under diffusion control [1, 32, 33]. Dendritic growth is initiated at some overpotentials belonging to the plateau of the limiting diffusion current density. For the group of intermediate metals, the minimum overpotential for the initiation of dendritic growth, $\eta_{\mathrm{i}}$ is given by Eq. (3) [1]:

$$
\eta_{\mathrm{i}}=\frac{b_{\mathrm{c}}}{2.3} \ln \frac{j_{\mathrm{L}}}{j_{0}}
$$

where $j_{\mathrm{L}}$ is the limiting diffusion current density and $b_{\mathrm{c}}$ is the cathodic Tafel slope. The critical overpotential for dendritic growth initiation, $\eta_{\mathrm{i}}$, denotes overpotential at which the system enters diffusion control of the electrodeposition. The outer limit of the diffusion layer of the macroelectrode was not disrupted by the formation of both the cauliflower-like agglomerates of grains and dendrites inside the plateau of the limiting diffusion current density.

The critical overpotential for instantaneous growth of dendrites, $\eta_{c}$, is given by Eq. (4) [1]:

$$
\eta_{\mathrm{c}}=\frac{b_{\mathrm{c}}}{2.3} \ln \left(\frac{j_{\mathrm{L}}}{j_{0}} \frac{\delta}{h}\right)
$$

where $\delta$ is the diffusion layer thickness and $h$ is the height of protrusion from which the growth of dendrite starts.

The critical overpotential for instantaneous dendritic growth, $\eta_{\mathrm{c}}$, is the overpotential at which diffusion control becomes complete, and this overpotential corresponds to the inflection point at the polarization curve [34]. The formation of only dendrites at an overpotential of $1000 \mathrm{mV}$ (Fig. 3, a and b) confirms this fact. After the inflection point, the electrodeposition system remains under diffusion control and the rapid increase in current density with the further increase in overpotential is due to the rapid growth of dendrites followed by the strong increase in the surface area. Considering the electrochemical definition of a dendrite, this sudden and rapid increase in current density after the inflection point can be mainly ascribed to the activation-controlled electrodeposition at the tips of the formed dendrites. It is very clear that both the trunk and branches of tips contribute to overall control of the electrodeposition process, causing the disruption of the outer limit of the diffusion layer of the macro-electrode. This is valid for metals with high overpotentials for hydrogen evolution, like Ag and normal metals. The situation is completely different for metals with medium $(\mathrm{Cu})$ and low (the inert metals) overpotentials for hydrogen evolution, which will be discussed later. For the intermediate metals, the difference between $\eta_{\mathrm{c}}$ and $\eta_{\mathrm{i}}$ (Eqs. (3) and (4)) will never reach zero, making this one of the substantial differences between intermediate and normal metals.

The Ag dendrites from the ammonium electrolyte were very similar to the $\mathrm{Ag}$ dendrites obtained in the presence of tungstosilicate [11] and citric [12] acids. The common characteristic of these electrolytes for $\mathrm{Ag}$ electrodeposition is their affiliation to the group of complex electrolytes. The surface morphology of these dendrites was completely different compared to $\mathrm{Ag}$ irregular forms which were created by the basic electrolytes [9]. The processes of $\mathrm{Ag}$ electrodeposition from the basic electrolytes belong to the rapid electrochemical processes $\left(j_{0} \rightarrow \infty\right)$ and the processes for the complex formation of $\operatorname{Ag}(\mathrm{I})$ ions lower the exchange current density (i.e. it decreases the rate of electrochemical process) and enable the transfer of $\mathrm{Ag}$ from the group of normal to the group of intermediate metals. In this way, analysis of the shape of $\mathrm{Ag}$ dendrites can be a good auxiliary criterion for the rapid estimation of the rate of the $\mathrm{Ag}$ electrodeposition process. The similarity of copper and silver dendrites obtained from the complex electrolytes with Au dendrites [35] (the third very important representative of the group of intermediate metals) clearly indicates that this shape of dendrites represents the typical form of a dendrite characterizing the group of intermediate metals.

\subsection{Effect of hydrogen evolution on $\mathrm{Cu}$ electrodeposition process - inhibition of dendritic growth}

The honeycomb-like structure (Fig. 3, c and d) was formed under the conditions of hydrogen evolution, which were vigorous enough to change the hydrodynamic conditions in the near-electrode layer [19]. The effect of evolved hydrogen on the change in the surface morphology of $\mathrm{Cu}$ from very branchy pine-like dendrites to honeycomb-like structures can be considered as follows:

Figure 4 shows the dependencies of the current of electrodeposition and the volumes of evolved hydrogen on the time of electrodeposition at overpotentials of 650 and $750 \mathrm{mV}$ (Fig. 4 a) and 850 and 1000 $\mathrm{mV}$ (Fig. 4 b). The current efficiency of hydrogen evolution in a time $t, \eta_{\mathrm{I}}\left(\mathrm{H}_{2}\right)$, were calculated by the use of Eq. (1) and the average values calculated as

$$
\eta_{\mathrm{I}, \mathrm{av}}\left(\mathrm{H}_{2}\right)=(1 / t) \int_{0}^{t} \eta_{\mathrm{I}}\left(\mathrm{H}_{2}\right) \mathrm{d} t
$$

are given in Table 1. 


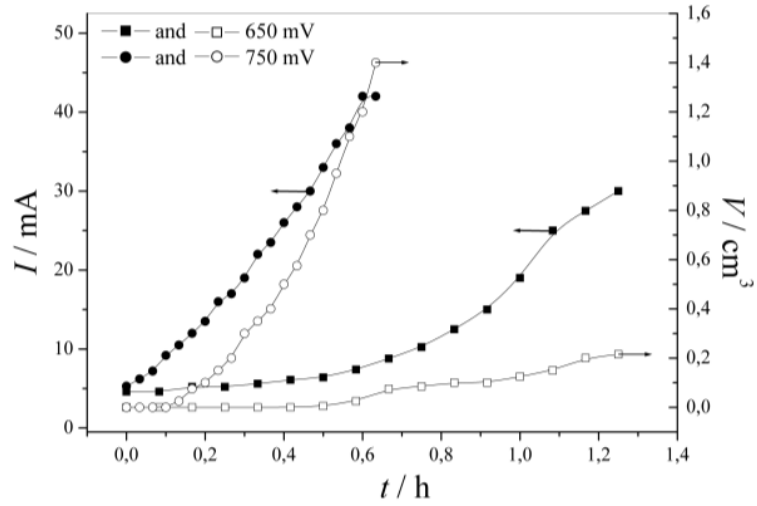

a)

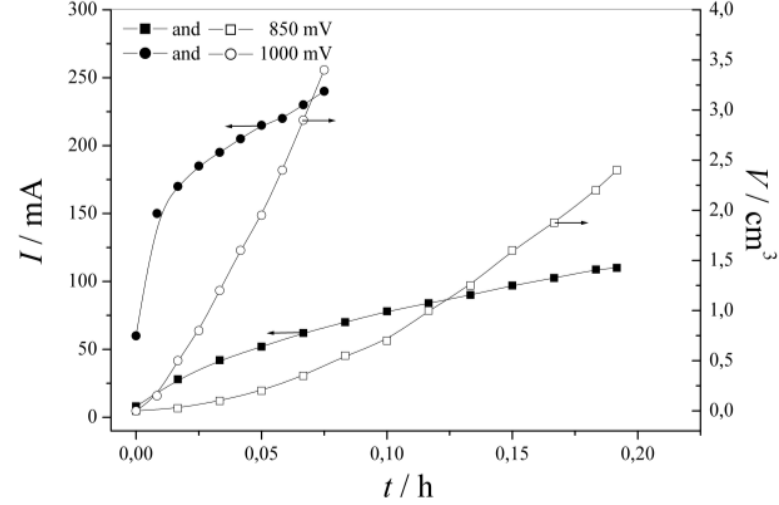

b)

Fig. 4. The dependencies of the current of electrodeposition and the volumes of evolved hydrogen on the time of electrodeposition obtained at overpotentials of: a) 650 and $750 \mathrm{mV}$, b) 850 and $1000 \mathrm{mV}$

Table 1

The values of the average current efficiency of hydrogen evolution, $\eta_{I, a v}\left(H_{2}\right)$, at overpotentials, $\eta$, of 650, 750, 850 and $1000 \mathrm{mV}$

\begin{tabular}{ccccc}
\hline \hline$\eta / \mathrm{mV}$ & 650 & 750 & 850 & 1000 \\
$\eta_{\mathrm{I}, \mathrm{av}}\left(\mathrm{H}_{2}\right) / \%$ & 2.0 & 14.5 & 30.7 & 46.8 \\
\hline \hline
\end{tabular}

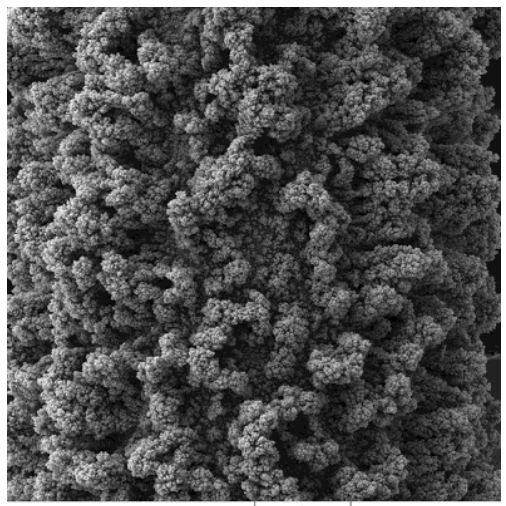

$200 \mu \mathrm{m}$

a)

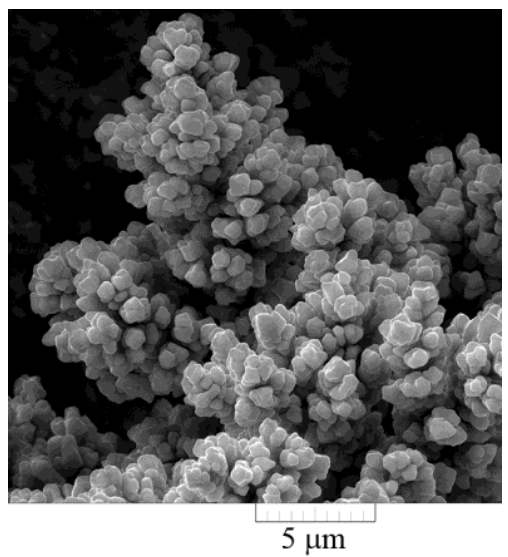

c)
Figure 5 shows the morphology of electrodeposited copper at an overpotential of $750 \mathrm{mV}$ ("top view", Fig. 5 a) and the typical elements of this surface morphology as follows: hole formed by detached hydrogen bubble (Fig. 5 b), degenerate dendrite (Fig. 5 c) and dish-like hole (Fig. 5 d).

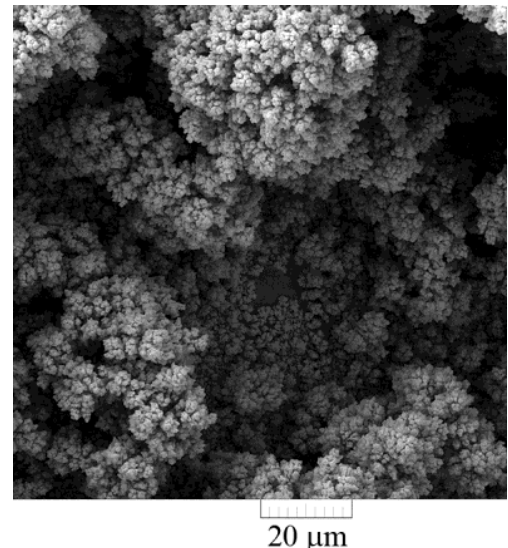

b)

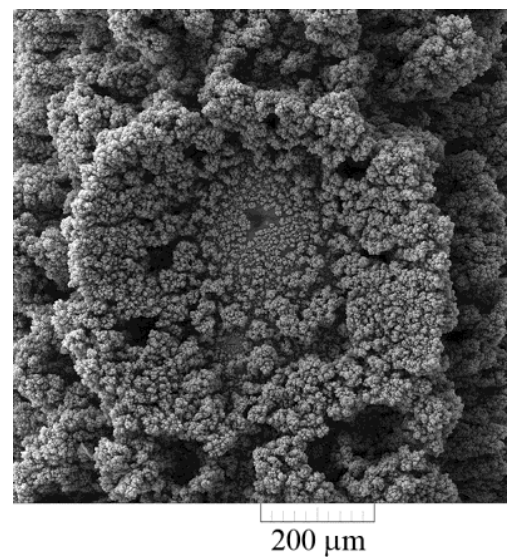

d)

Fig. 5. a) The top view and the typical elements of the surface morphology: b) hole formed by detached hydrogen bubble, c) degenerate dendrite and d) dish-like hole obtained by $\mathrm{Cu}$ electrodeposition at an overpotential of $750 \mathrm{mV}$ 
The analysis of the surface morphology of copper obtained at an overpotential of $850 \mathrm{mV}$ (Fig. 6) reveals the formation of the honeycomblike structure at this overpotential. The analysis of Figs. 2, c and d, 3, c and d, 5 and 6 provides complete insight into the effect of hydrogen evolution on the copper electrodeposition process. Hydrogen evolution as the second reaction to copper electrodeposition commences at some overpotentials belonging to the plateau of the limiting diffusion current density, which is confirmed by the presence of individual holes in the morphology of $\mathrm{Cu}$ deposits that are electrodeposited at $650 \mathrm{mV}$ (Fig. $2 \mathrm{c}$ ).

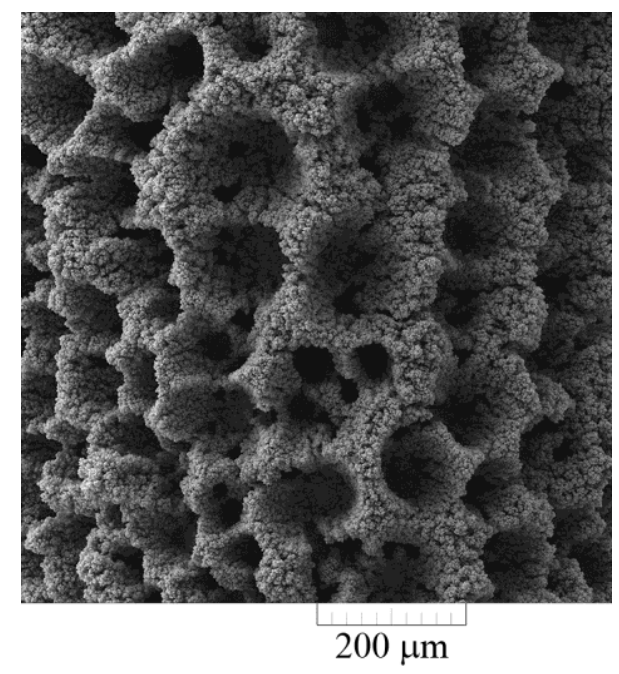

Fig. 6. The typical honeycomb-like structure obtained by $\mathrm{Cu}$ electrodeposition at an overpotential of $850 \mathrm{mV}$

The critical overpotential for the beginning of hydrogen evolution can be estimated from the dependence of the average current efficiency of hydrogen evolution, $\eta_{\mathrm{I}, \mathrm{av}}\left(\mathrm{H}_{2}\right)$, on an overpotential to be approximately $590 \mathrm{mV}$ (Fig. 7). The amount of evolved hydrogen at $650 \mathrm{mV}\left(\eta_{\mathrm{I}, \mathrm{av}}\left(\mathrm{H}_{2}\right)=2.0 \%\right)$ was not sufficient to achieve any effect on the $\mathrm{Cu}$ electrodeposition process. The strong non-uniform electrode surface obtained at $650 \mathrm{mV}$ (very branchy dendrites, small cauliflower-like agglomerates of $\mathrm{Cu}$ grains, and rare holes with an origin of detached hydrogen bubbles) clearly confirms that the diffusion layer of the macroelectrode is not disturbed by this amount of generated hydrogen.

Increasing the overpotential intensifies hydrogen evolution and the effect of evolved hydrogen on $\mathrm{Cu}$ electrodeposition becomes visible in the morphology of $\mathrm{Cu}$ deposits obtained at $750 \mathrm{mV}$ $\left(\eta_{\mathrm{I}, \mathrm{av}}\left(\mathrm{H}_{2}\right)=14.5 \%\right.$; Fig. 5 a). Dendritic growth is partially inhibited by evolved hydrogen and degenerate dendrites (Fig. 5 c) are formed instead of normal dendrites by electrodeposition at this over- potential. Due to the more intense hydrogen evolution at $750 \mathrm{mV}$, the number of holes formed is larger than that at $650 \mathrm{mV}$. Also, large holes with clearly defined shoulders (dish-like holes) [20] were formed at this overpotential. Also, evolved hydrogen achieved an effect on the hydrodynamic conditions in the near-electrode layer, but the nonuniformity of the electrode surface was not completely eliminated. The evolved hydrogen caused stirring of the electrolyte in the near-electrode layer, leading to a decrease in the thickness of the diffusion layer, an increase in the limiting diffusion current density and a decrease in the degree of diffusion control of the electrodeposition process.

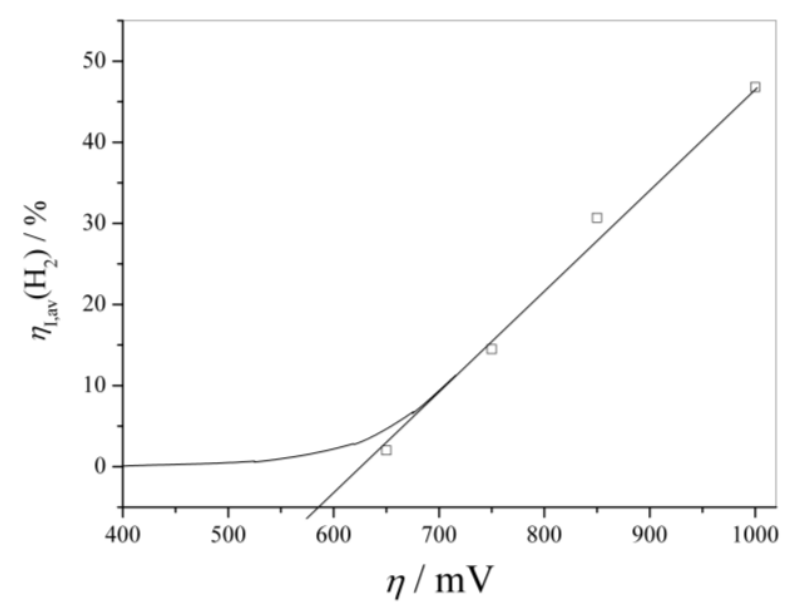

Fig. 7. The determination of the critical overpotential for the beginning of hydrogen evolution from $0.1 \mathrm{M} \mathrm{CuSO}_{4}$ in $0.5 \mathrm{M} \mathrm{H}_{2} \mathrm{SO}_{4}$

The further increase in overpotential of the electrodeposition intensified the hydrogen evolution reaction. Above the some critical value, hydrogen evolution was vigorous enough and a full change in the hydrodynamic conditions in the nearelectrode layer was observed. Then, dendritic growth was completely inhibited and the honeycomb-like structures were formed (Figs. $3 \mathrm{c}$ and 6). As a result, the uniform distribution of morphological forms in the honeycomb-like structures (holes and cauliflower-like agglomerates around them) was attained. Due to intensification of the hydrogen evolution reaction, the number of holes formed at an overpotential of $1000 \mathrm{mV}$ was larger than formed at an overpotential of $850 \mathrm{mV}$. Simultaneously, the pore size and the wall width among holes decreased with increasing overpotential of electrodeposition. The number and size of holes, as well as the wall width, do not depend only on overpotential to the electrodeposition, but to regimes of electrolysis [21, 22, 36-38] or the inclusion of additives [39, 40]. 
The mechanism behind the formation of the honeycomb-like structures is completely different to that responsible for the formation of dendrites. The concept of "effective overpotential" was proposed to explain the formation of this type of structure [19]. According to this concept, when hydrogen evolution is vigorous enough, the electrodeposition process occurs at an overpotential which is effectively lower than that specified, and this overpotential is denoted as "effective" in a deposition process. From the morphological point of view, this means that the morphologies of metal deposits become similar to those obtained at some lower overpotentials at which hydrogen evolution does not occur or is very slow. The formation of cauliflower-like agglomerates of copper grains instead of branchy dendrites clearly indicates the existence of a smaller degree of diffusion control at overpotentials of 850 and $1000 \mathrm{mV}$ than at 650 $\mathrm{mV}$. Hence, the zone of the fast increase of the current density with increasing the overpotential after the inflection point is related to the hydrogen evolution reaction and its effect on the hydrodynamic conditions in the near-electrode layer.

\subsection{The transitional characteristics of the intermediate metals between the normal and inert metals}

It can be concluded from the above consideration that the typical shape of dendrites which characterize the intermediate metals is pine-like with corncob-like elements as branches. Hydrogen evolution is a crucial factor leading to the inhibi- tion of dendritic growth and changes in the surface morphology of $\mathrm{Cu}$ from dendrites to cauliflowerlike particles formed around holes, making both dendrites and cauliflower-like particles via the typical powder forms, thus characterizing the intermediate metals. Also, it is clear that there is a correlation between the polarization characteristics and morphology of electrodeposited metal. The same response for the polarization curve gives a completely different surface morphology in the zone responsible for the rapid increase in the current density with the overpotential after the inflection point. In the case of silver, the rapid increase in the current density with increasing overpotential is ascribed to the activation controlled electrodeposition at the tips of dendrites. This polarization behaviour for $\mathrm{Ag}$ is similar to the polarization characteristics of the normal metals (the high $j_{0}$, the high hydrogen overpotential) [41, 42]. In the case of copper, the fast growth of the current density after the inflection point is due to competition between the hydrogen evolution reaction and the copper electrodeposition process. This continuous increase in the current density with increasing overpotential due to the strong effect of evolved hydrogen on the hydrodynamic conditions in the near-electrode layer is a characteristic of the inert metals (the low $j_{0}$, the low hydrogen overpotential). In this way, the transitional character of the intermediate metals between the normal and inert metals can be determined and defined. A comparative survey of the polarization and morphological characteristics of these typical representatives of the intermediate metals is given in Figure 8.

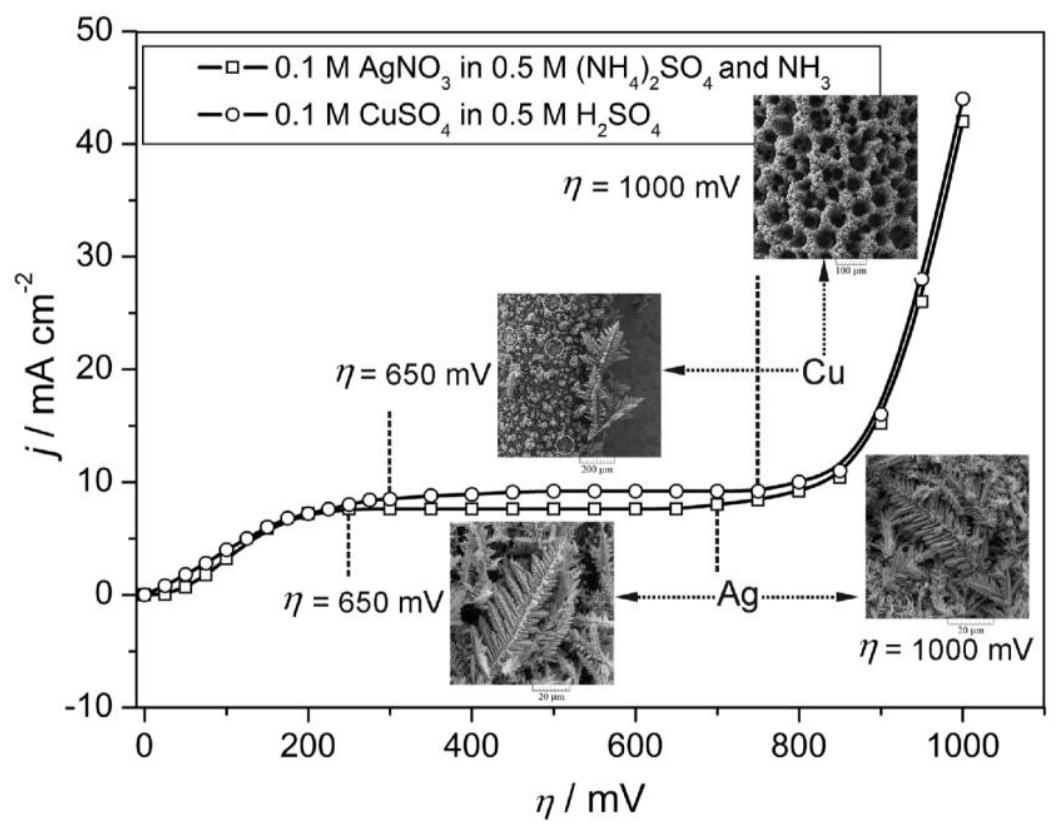

Fig. 8. Comparative survey of the polarization and morphological characteristics of copper and silver 
Nevertheless, copper electrodeposition processes at high overpotentials where hydrogen evolution reactions occur parallel to $\mathrm{Cu}$ electrodeposition can be seen as an introduction to understanding of metal electrodeposition from the third group (the inert metals). It should be noted that the copper dendrites and cauliflower-like particles $[4,5]$, as well as the honeycomb-like structures $[17,18$, 37] obtained in the galvanostatic regimes of electrolysis, were very similar those obtained in the potentiostatic regime and shown here. The most important metals from the group of inert metals from both scientific and technological points of view are $\mathrm{Fe}, \mathrm{Ni}$ and $\mathrm{Co}$. Electrodeposition of these metals is always accompanied by a hydrogen evolution reaction. At the macro-level, morphologies of the different irregular forms (or powder particles) of these metals were comparable to those observed with copper electrodeposition in the hydrogen co-deposition range. Holes formed from detached hydrogen bubbles, cauliflower-like agglomerates of metal grains and globules were the dominant morphological forms of powder particles obtained by the electrodeposition of inert metals such as $\mathrm{Ni}, \mathrm{Co}$ and $\mathrm{Fe}[15,16,43]$. All of these powder particles were formed under the condition of vigorous hydrogen evolution and the concept of "effective overpotential" is applicable to explain the formation of these powder particles. Jović et al. [15] analyzed polarization characteristics for the electrodeposition of $\mathrm{Co}$ and $\mathrm{Ni}$ and showed that the shape of polarization curves for these metals is a consequence of the so-called "electrode effect" which is connected to the bubble formation at high current densities; as a result, the evolution of bubbles became the rate-limiting step of the electrochemical process. The current for hydrogen evolution at more negative potentials reached $60-70 \%$ of the total current, which is in excellent agreement with the values obtained during the electrodeposition of copper in the hydrogen co-deposition range. Simultaneously, the honeycomb-like structures of nickel [44] were very similar to those of copper. Under the determined electrodeposition conditions, very branchy nickel dendrites were formed [14] which were more similar to the dendrites of intermediate metals than those belonging to the group of normal metals. The shape of $\mathrm{Ni}, \mathrm{Co}$ and $\mathrm{Fe}$ powder particles did not depend on the composition of solution, which is understandable due to the vigorous hydrogen evolution during the formation of these particles via the electrolysis processes.

It is clear that macrostructures of copper deposits obtained in the hydrogen co-deposition range are comparable with those characterizing the group of inert metals. The appearance of macropores (the honeycomb-like structures) and cauliflower-like agglomerates of copper grains in the hydrogen co-deposition range approached the structural characteristics of copper to those from the group of inert metals, additionally establishing the transitional characteristic of the intermediate metals between normal and inert metals.

\section{CONCLUSIONS}

The processes responsible for the electrodeposition of silver (the ammonium electrolyte) and copper at the high overpotentials, as the typical representatives of intermediate metals, were analyzed. The polarization characteristics were correlated with the morphologies of silver and copper deposits characterized by scanning electron microscopy (SEM).

The dendrites of silver and copper obtained at the overpotentials belonging to the plateaus of the limiting diffusion current density were very similar to each other. They had a pine-like shape constructed from the corncob-like branches as the basic elements. This type of dendrite represents the typical form of dendrites characterizing the intermediate metals.

A completely different situation was observed in the part of the polarization curves characterized by the rapid increase in the current density with increasing overpotential. Due to the lower overpotential for hydrogen evolution, the process of $\mathrm{Cu}$ electrodeposition was strongly affected by the hydrogen evolution reaction. Unlike silver dendrites, which have similar results to those obtained at the plateaus of the limiting diffusion current density, holes formed by detached hydrogen bubbles surrounded by cauliflower-like agglomerates (the honeycomb-like structure) were obtained by $\mathrm{Cu}$ electrodeposition in this zone.

The typical irregular (or powder) morphological forms (the pine-like shape of a dendrite and cauliflower-like particles) characterizing the intermediate metals are defined. By analyzing the polarization and morphological characteristics of $\mathrm{Cu}$ and $\mathrm{Ag}$, the transitional character of intermediate metals between the normal and inert metals is established.

Acknowledgements. The work was supported by the Ministry of Education, Science and Technological Development of the Republic of Serbia under the research project: "Electrochemical synthesis and characterization of nanostructured functional materials for application in new technologies" (No. 172046). 


\section{REFERENCES:}

[1] K. I. Popov, S. S. Djokić, B. N. Grgur, Fundamental aspects of electrometallurgy, New York, Kluwer Academic/Plenum Publishers, 2002, pp 1-305.

[2] R.Winand, Electrodeposition of metals and alloys - new results and perspectives, Electrochim. Acta, 39, 10911105 (1994).

[3] V. M. Kozlov, L. Peraldo Bicelli, Influence of the nature of metals on the formation of the deposit's polycrystalline structure during electrocrystallization, J. Cryst. Growth, 203, 255-260 (1999).

[4] G. Orhan, G. Hapci, Effect of electrolysis parameters on the morphologies of copper powder obtained in a rotating cylinder electrode cell, Powder Technol., 201, 57-63 (2010).

[5] G. Orhan, G. G. Gezgin, Effect of electrolysis parameters on the morphologies of copper powder obtained at high current densities, J. Serb. Chem. Soc., 77, 651665 (2012).

[6] N. D. Nikolić, G. Branković, M. G. Pavlović, Correlate between morphology of powder particles obtained by the different regimes of electrolysis and the quantity of evolved hydrogen, Powder Technol., 221, 271-277 (2012).

[7] Y. Ni, Y. Zhang, L. Zhang, J. Hong, Mass synthesis of dendritic Bi nanostructures by a facile electrodeposition route and influencing factors. CrystEngComm, 13, 794799 (2011)

[8] M. Yang, Fern-shaped bismuth dendrites electrodeposited at hydrogen evolution potentials, J. Mater. Chem., 21, 3119-3124 (2011).

[9] C. Ding, C. Tian, R. Krupke, J. Fang, Growth of nonbranching $\mathrm{Ag}$ nanowires via ion migrational-transport controlled 3D electrodeposition, CrystEngComm, 14, 875-879 (2012).

[10] T-H. Lin, C-W. Lin, H-H. Liu, J-T. Sheu, W-H. Hung, Potential controlled electrodeposition of gold dendrites in the presence of cysteine, Chem. Commun., 47, 2044 2046 (2011)

[11] J. Han, J. Liu, Electrodeposition of Crystalline Dendritic Silver in 12-Tungstosilicate Acid System, J. Nanoeng. Nanomanuf., 2, 171-174 (2012).

[12] M. V. Mandke, S-H. Han, H. M. Pathan, Growth of silver dendritic nanostructures via electrochemical route, CrystEngComm, 14, 86-89 (2012).

[13] J. Wang, L. Wei, L. Zhang, Y. Zhang, C. Jiang, Electrolytic approach towards the controllable synthesis of symmetric, hierarchical, and highly ordered nickel dendritic crystals, CrystEngComm, 14, 1629-1636 (2012).

[14] N. D. Nikolić, H. Wang, H. Cheng, C. Guerrero, E. V. Ponizovskaya, G. Pan, N. Garcia, Magnetoresistance Controls Arboreous Bead-Dendritic Growth of Magnetic Electrodeposits: Experimental and Theoretical Results, J. Electrochem. Soc., 151, C577-C584 (2004).

[15] V. D. Jović, B. M. Jović, V. M. Maksimović, M. G. Pavlović, Electrodeposition and morphology of $\mathrm{Ni}, \mathrm{Co}$ and Ni-Co alloy powders: Part II. Ammonium chloride supporting electrolyte, Electrochim. Acta, 52, 4254 4263 (2007).

[16] V. D. Jović, V. M. Maksimović, M. G. Pavlović, K. I. Popov, Morphology, internal structure and growth mechanism of electrodeposited $\mathrm{Ni}$ and Co powders, J. Solid State Electrochem., 10, 373-379 (2006).

[17] H. Shin, J. Dong, M. Liu, Nanoporous Structures Prepared by an Electrochemical Deposition Process, Adv. Mater., 15, 1610-1614 (2003).

[18] Y. Li, W Jia, Y. Song, X. H. Xia, Superhydrophobicity of 3D porous copper films prepared using the hydrogen bubble dynamic template, Chem. Mater., 19, 5758-5764 (2007).

[19] N. D. Nikolić, K. I. Popov, Lj. J. Pavlović, M. G. Pavlović, The effect of hydrogen codeposition on the morphology of copper electrodeposits. I. The concept of effective overpotential, J. Electroanal. Chem., 588, 8898 (2006).

[20] N. D. Nikolić, Lj. J. Pavlović, M. G. Pavlović, K. I. Popov, Formation of dish-like holes and a channel structure in electrodeposition of copper under hydrogen co-deposition, Electrochim. Acta, 52, 8096-8104 (2007).

[21] N. D. Nikolić, G. Branković, M. G. Pavlović, K. I. Popov, The effects of the pause to pulse ratio in the regime of pulsating overpotential on the formation of honeycomb-like structures, Electrochem. Commun., 11, 421-424 (2009).

[22] N. D. Nikolić, G. Branković, Effect of parameters of square-wave pulsating current on copper electrodeposition in the hydrogen co-deposition range, Electrochem. Commun., 12, 740-744 (2010).

[23] S. Cherevko, X. Xing, C-H. Chung, Electrodeposition of three-dimensional porous silver foams, Electrochem. Commun., 12, 467-470 (2010).

[24] S. Cherevko, C. Chung, Impact of key deposition parameters on the morphology of silver foams prepared by dynamic hydrogen template deposition, Electrochim. Acta, 55, 6383-6390 (2010).

[25] S. Cherevko, C. Chung, Direct electrodeposition of nanoporous gold with controlled multimodal pore size distribution, Electrochem. Commun., 13, 16-19 (2011).

[26] R. Sivasubramanian, M. V. Sangaranarayanan, Electrodeposition of silver nanostructures: from polygons to dendrites, CrystEngComm, 15, 2052-2056 (2013).

[27] M. Rosso, E. Chassaing, V. Fleury, J-N. Chazalviel, Shape evolution of metals electrodeposited from binary electrolytes, J. Electroanal. Chem., 559, 165-173 (2003).

[28] K. I. Popov, N. V. Krstajić, S. R. Popov, Fundamental aspects of plating technology. II. Morphological aspects of metal electrodeposition from complex salt solutions, Surf. Technol., 20, 203-208 (1983).

[29] S. Trasatti, Work function, electronegativity, and electrochemical behaviour of metals: III. Electrolytic hydrogen evolution in acid solutions, J. Electroanal. Chem., 39, 163-184 (1972).

[30] N. D. Nikolić, Lj. J. Pavlović, M. G. Pavlović, K. I. Popov, Morphologies of electrochemically formed copper powder particles and their dependence on the quantity of 
evolved hydrogen, Powder Technol., 185, 195-201 (2008).

[31] G. Wranglen, Dendrites and growth layers in the electrocrystallization of metals. Electrochim. Acta, 2, 130-146 (1960).

[32] J. W. Diggle, A. R. Despić, J.O’M. Bockris, The mechanism of the dendritic electrocrystallization of zinc, J. Electrochem. Soc., 116, 1503-1514 (1969).

[33] A. R. Despić, K. I. Popov, Transport controlled deposition and dissolution of metals, in: Modern Aspects of Electrochemistry, B. E. Conway, J. O`M. Bockris (Eds), Vol 7, Plenum Press, 1972, pp 199-313.

[34] N. D. Nikolić, K. I. Popov, P. M. Živković, G. Branković, A new insight into the mechanism of lead electrodeposition: ohmic-diffusion control of the electrodeposition process, J. Electroanal. Chem., 691, 66-76 (2013).

[35] Z-Y. Lv, A-Q. Li, Y. Fei, Z. Li, J-R. Chen, A-J. Wang, J-J. Feng, Facile and controlled electrochemical route to three-dimensional hierarchical dendritic gold nanostructures, Electrochim. Acta, 109, 136-144 (2013).

[36] N. D. Nikolić, G. Branković, V. M. Maksimović, Effect of the anodic current density on copper electrodeposition in the hydrogen co-deposition range by the reversing current (RC) regime, J. Electroanal. Chem., 661, 309316 (2011).

[37] N. D. Nikolić, G. Branković, K. I. Popov, Optimization of electrolytic process of formation of open and porous copper electrodes by the pulsating current (PC) regime, Mater. Chem. Phys., 125, 587-594 (2011).

[38] N. D. Nikolić, G. Branković, M. G. Pavlović, Effect of the electrolysis regime on the structural characteristics of honeycomb-like electrodes, Maced. J. Chem. Chem. Eng., 32, 79-87 (2013).

[39] H. Shin, M. Liu, Copper Foam Structures with Highly Porous Nanostructured Walls, Chem. Mater., 16, 54605464 (2004).

[40] J.-H. Kim, R.-H. Kim, H.-Sang Kwon, Preparation of copper foam with 3-dimensionally interconnected spherical pore network by electrodeposition, Electrochem. Commun., 10, 1148-1151 (2008).

[41] N. D. Nikolić, V. M. Maksimović, G. Branković, Morphological and crystallographic characteristics of electrodeposited lead from the concentrated electrolyte, RSC Adv., 3, 7466-7471 (2013).

[42] N. D. Nikolić, Dj. Dj. Vaštag, P. M. Živković, B. Jokić, G. Branković, Influence of the complex formation on the morphology of lead powder particles produced by the electrodeposition processes, Adv. Powder Technol., 24, 674-682 (2013).

[43] V. D. Jović, B. M. Jović, M. G. Pavlović, Electrodeposition of $\mathrm{Ni}$, $\mathrm{Co}$ and $\mathrm{Ni}-\mathrm{Co}$ alloy powders, Electrochim. Acta, 51, 5468-5477 (2006).

[44] C. A. Marozzi, A. C. Chialvo, Development of electrode morphologies of interest in electrocatalysis. Part 1: Electrodeposited porous nickel electrodes, Electrochim. Acta, 45, 2111-2120 (2000). 